\title{
THE INFLUENCE OF YEAR-ROUND WEATHER CONDITIONS AND FERTILIZATION ON THE PHYTOMASS YIELD OF AMARANTH (AMARANTHUS L.)
}

\author{
Ladislav ILLÉŠ, Eva CANDRÁKOVÁ, Richard POSPIŠIL, Jozef ŽEMBERY
}

Slovak University of Agriculture in Nitra, Slovakia

\begin{abstract}
In the years 2010 and 2011, a field trial was established in the administrative area Kolinany, Barack farm. We evaluated the growth of aboveground phytomass depending on different levels of fertilization. In the climatically unbalanced growing years, the phytomass yield of amaranth was different. Extremely wet conditions during the growing season exceeding long-term normal precipitation confirmed the assumption of high growth of aboveground phytomass in the observed amaranth genotype. In 2010 , the highest amaranth aboveground dry matter in phytomass reached $3231.40 \mathrm{~g} \mathrm{~m}^{2}$ in the variant with the fertilization dose of $150 \mathrm{~kg} \mathrm{ha}^{-1}$. In the climatically different year 2011 with lower precipitation, the highest aboveground phytomass yield of $3956.95 \mathrm{~g} \mathrm{~m}^{2}$ was reached in the fertilized variant as well.
\end{abstract}

Keywords: amaranth, yield, biomass, fertilization

Amaranth belongs to one year plants producing biomass from which we obtain energy, and thus it can replace conventional fuels. The uses of biomass for energy purposes depend primarily on the physical and chemical properties of the biomass. Amaranth is used for biochemical conversion of biomass methane fermentation (biogas) or thermochemical conversion of biomass by heat (combustion). Except of energy production, amaranth is also used as an industrial crop, pseudocereal, animal feed, feed dye, ornamental plant, and a plant with healing properties (Habán a Illéš, 2001). The aboveground mass can be used as livestock forage or for energy purposes as fuel or raw material for processing industry (Jamriška, 2001). Interspecific genotypes are characterized by massive biomass production and they are used as animal feed, energy carriers and raw materials for pharmaceutical industry (Žajová, 2001).

On the EXBA Dolná Malanta SUA Nitra, the aboveground biomass of the major and minor product harvested in the period of 1994-1996 was analyzed. After experimental analysis of the production process and the share of the main product of Amaranthus hypochondriacus L., the yields in amount from 10.84 to $11.61 \mathrm{t} \mathrm{ha}^{-1}$ were recorded (Pospišil, 2010).

The occurrence of gigantism in amaranth was recorded in the following places: the Botanical Gardens of SUA, Mojmírovce and Malý Šariš. The plants there were three meters high, they had thick stems and were very leafy. The aboveground mass of one plant was $2.5 \mathrm{~kg}$. At the density of 100000 individuals per 1 ha ( 10 plants per $\left.1 \mathrm{~m}^{2}\right)$, the yield of the aboveground biomass reached $250 \mathrm{t} \mathrm{ha}^{-1}$ of fresh phytomass which is 5 times more than in silage maize with the yield of $50 \mathrm{t} \mathrm{ha}^{-1}$ (Húska 1997).

In the evaluation of the yield of amaranth seeds carried out in 2001 (Illéš et al., 2010), with the dose of $120 \mathrm{~kg}$ N.ha- ${ }^{-1}$, the yield increased by only $5.4 \%$ compared to the unfertilized control group, but in 2002, after the application of $240 \mathrm{~kg} \mathrm{~N} \mathrm{ha}^{-1}$, the yield increased by $53.6 \%$. Better rainfall conditions in 2002 had significant impact on the yield increase.

\section{Material and methods}

In the area of Kolínany on the Barack farm, experiments with amaranth were established in 2010 and 2011; the coordinates of the exact location are $48^{\circ} 20^{\prime} \mathrm{N}, 18^{\circ}$ $14^{\prime} \mathrm{E}$. Soil type: brown soil, loamy soil, the altitude area is $180 \mathrm{~m}$ a. s. I.

The Amaranthus caudatus genotype originated in Peru was used for the experiment. The width of lines was $0.5 \mathrm{~ms}$ with the stand organization of $160,000-220,000$ plant. $\mathrm{ha}^{-1}$ and the plot size of $5 \times 2 \mathrm{~m}^{2}$. The following variants of fertilization were used: $\mathrm{H} 1$ - unfertilized control group, $\mathrm{H} 2$ $\mathrm{N} 50 \mathrm{~kg} \mathrm{ha}^{-1}, \mathrm{H} 3-100 \mathrm{~kg} \mathrm{~N} \mathrm{ha}^{-1}$ and $\mathrm{H} 4-150 \mathrm{~kg} \mathrm{~N} \mathrm{~h}^{-1}$.

Sampling of the plant material from the length of two meters took place during the growing season of all observed fertilization variants. There were three sampling dates each year (July 21, August 26, October 12 in 2010 and 29 July, 22 August, 5 October in 2011) when we studied the number of plants per an area unit and the weight of the aboveground dry matter biomass (stems, leaves, inflorescences).

The sowing of 2.00 to $2.30 \mathrm{~kg} \mathrm{ha}{ }^{-1}$ was performed on May 28, 2010 and May 10, 2011, respectively. The weed control was ensured by chemical and mechanical means. The pre-emergence application of Dominator herbicide (2.5 I ha-1) took place during the growing season and the post-emergence application of Targa Super herbicide (1.2 I $\mathrm{ha}^{-1}$ ) in the appropriate period. In 2011, the pre-emergence application of the Cosmic preparation (2.5 I ha-1) and the post-emergence application of Targa Super preparation (1.2 I ha-1) was performed. In addition to chemical weed control treatment, mechanical machining also took place.

\section{Results and discussion}

Significant results include the evaluation of biomass yields and its growth during the growing season in relation to the parameters of production technology and the impact 


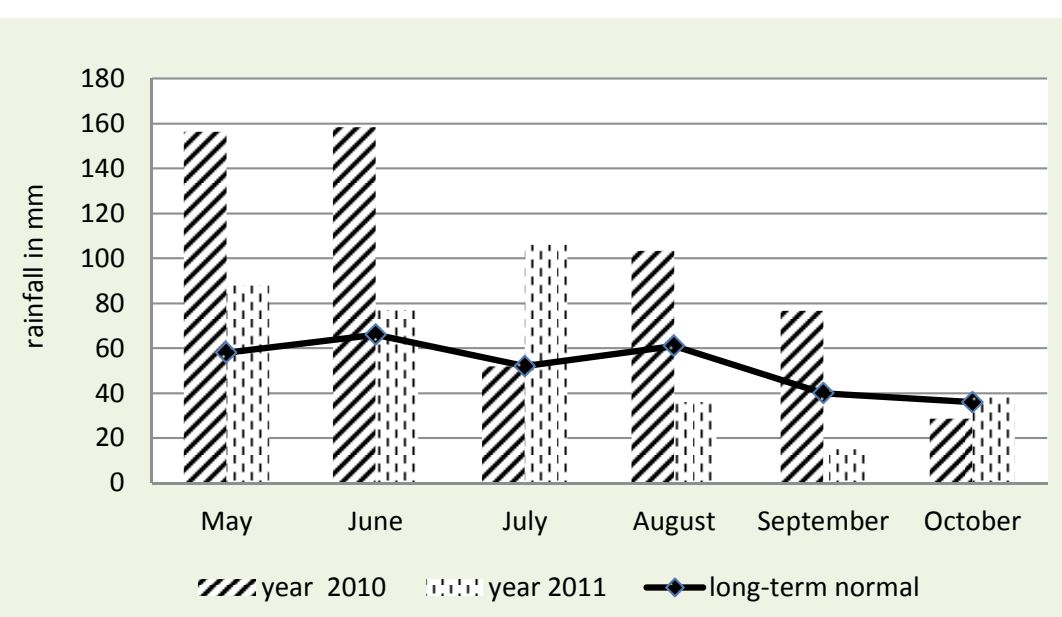

Figure 1 Monthly rainfall in mm during the growing season in 2010 and 2011 (Koliňany station)

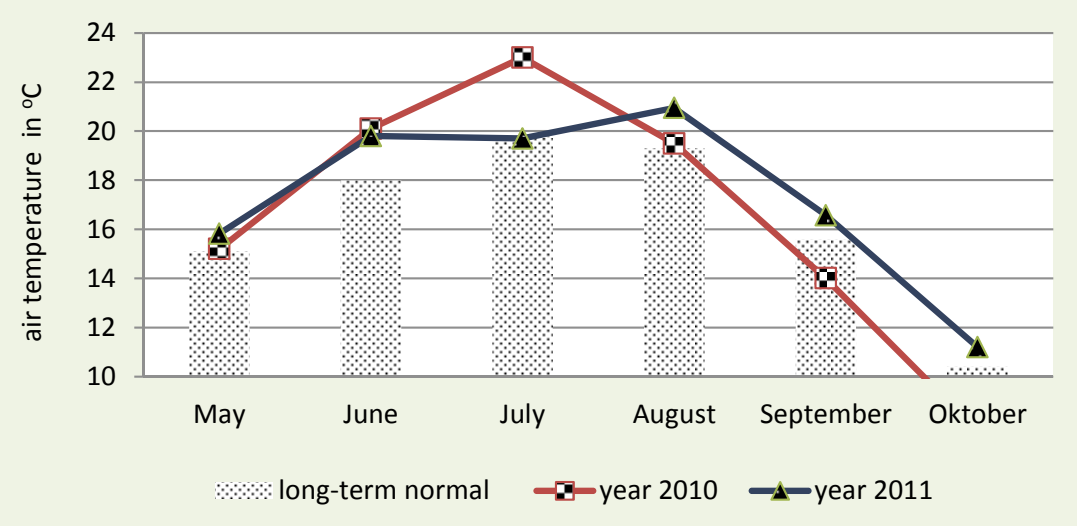

Figure 2 The average air temperature in ${ }^{\circ} \mathrm{C}$ in 2010 and 2011

of weather conditions throughout the year.

Amaranth can produce large amounts of high quality material in a relatively short growing period (95120 days), which requires the creation of appropriate conditions for the root system, i.e. ensuring an adequate supply of nutrients, water and air.

The sowing of 2010 was performed in bad weather conditions on May 28. In April and May, precipitation reached 244.4 and $256.7 \%$ of the long-term normal value, respectively (Figure 1). The sowing dates in that period were postponed due to excessive rainfall.

Despite excessive rainfall, the crop growth was very poor and at the beginning of the growing season, it was negatively affected by the emerging drought, therefore it was necessary to perform hoeing by hand.
The sowing of 2011 was performed on May 10, i.e. 18 days earlier than in the previous year. The precipitation in May reached $157.1 \%$ of the longterm normal value, which was more favourable to the onset of the growing season in 2011.

In 2010, the first sampling was performed 53 days after the sowing, i.e. July 21 , when plants grew to $0.15-$ $0.40 \mathrm{~ms}$ with the leaf representation reaching $57.4 \%$ in variant $\mathrm{H} 1$.

In 2011, the first sampling was performed 80 days after the sowing, i.e. July 29, when the plants grew to 1.02 $1.27 \mathrm{~ms}$ with the leaf representation reaching $6 \%$ in variant $\mathrm{H} 1$.

The second sampling of biological material in 2010 was performed on August 26. At that time, the plants reached the height of $1.36 \mathrm{~m}$ in $\mathrm{H} 1$ variant and $1.58 \mathrm{~m}$ in $\mathrm{H} 3$ variant. The nitrogen dose of $100 \mathrm{~kg} \mathrm{ha}^{-1}$ significantly affected the plant height when compared to the control group.
At this time, inflorescence with the length of 0.04 to $0.61 \mathrm{~m}$ appeared on some plants, the leaf representation reached $27.9 \%$ and the stem representation reached $70.6 \%$.

At the time of the second sampling of biological material in 2011, the plants reached the height of $1.37 \mathrm{~m}$ in the $\mathrm{H} 2$ variant and the height of $1.72 \mathrm{~m}$ in the $\mathrm{H} 4$ variant. The difference between these variants was $0.40 \mathrm{~m}$. At this time, the length of the inflorescence was 0.04 to $0.11 \mathrm{~m}$. The leaf representation reached $29.2 \%$ and the stem representation reached $69.5 \%$.

At the time of the third sampling of plants in 2010, i.e. just before harvest, the plants amounted to the height of $2.2 \mathrm{~m}$ in the unfertilised variant and $2.30 \mathrm{~m}$ in the fertilized variant $(\mathrm{H} 3)$. Inflorescence reached 0.28 to 0.40 meters, leaf representation reached $23.9 \%$ and stem representation reached $67.1 \%$.

At the time of the third sampling of plants in 2011, the plants reached the height of 2.35 in the unfertilized variant and $2.54 \mathrm{~m}$ in the fertilized variant $(\mathrm{H} 4)$. Inflorescence reached the maximum value of 0.68 meters in the $\mathrm{H} 4$ variant, leaf representation reached $11.2 \%$ and stem representation reached $76.6 \%$.

When evaluating the dry matter of leaves, stems and inflorescence, a significant influence of fertilization on the increase of the total biomass of amaranth is evident (Table 1).

Higher phytomass values were reached in the first sampling in 2011 (593.84-1052.24 $\mathrm{g} \mathrm{m}^{2}$ ) because of the earlier dates of sowing in 2011.

In the second sampling, an evident increase in aboveground biomass of dry matter with the weight of $3087 \mathrm{~g} \mathrm{~m}^{2}$ was observed mainly in $\mathrm{H} 4$ in 2010 . In 2011, the phytomass weight in the same variant reached $2168.64 \mathrm{~g} \mathrm{~m}^{2}$.

In the third sampling, we found a more significant weight increase compared to the previous sampling. In 2011, the values of phytomass were higher, they ranged from 2335.04 to $3956.95 \mathrm{~g} \mathrm{~m}^{2}$. In 2010, depending on the fertilization intensity, said values ranged from 1642.60 to $3231.40 \mathrm{~g} \mathrm{~m}^{2}$.

The aboveground biomass of dry matter at harvest (in the third sampling) ranged from $12.8 \%(\mathrm{H} 3)$ to 
Table 1 The increase in the above-ground biomass of amaranth in g.m $^{-2}$ in 2010 and 2011

\begin{tabular}{|c|c|c|c|c|c|c|c|c|}
\hline \multicolumn{9}{|l|}{ 1. sampling } \\
\hline \multirow[t]{2}{*}{ Fertilization } & \multicolumn{2}{|c|}{ Weight of leaves $\mathbf{g ~ m}^{2}$} & \multicolumn{2}{|c|}{ Weight of stems $\mathbf{g} \mathbf{~ m}^{2}$} & \multicolumn{2}{|c|}{ Weight of infl. $\mathbf{g ~ m}^{2}$} & \multicolumn{2}{|c|}{ Weight of plants $\mathbf{g ~ m}^{2}$} \\
\hline & 2010 & 2011 & 2010 & 2011 & 2010 & 2011 & 2010 & 2011 \\
\hline $\mathrm{H} 1$ & 66.00 & 235.04 & 48.80 & 357.32 & - & 1.48 & 114.80 & 593.84 \\
\hline $\mathrm{H} 2$ & 93.20 & 288.68 & 50.80 & 413.84 & - & 0.84 & 144.00 & 703.36 \\
\hline $\mathrm{H} 3$ & 79.60 & 414.92 & 56.80 & 672.00 & - & 1.56 & 136.40 & 1088.48 \\
\hline $\mathrm{H} 4$ & 81.20 & 392.80 & 59.00 & 657.24 & - & 2.20 & 140.20 & 1052.24 \\
\hline $\bar{x}$ & 80.00 & 332.86 & 53.85 & 525.10 & - & 1.52 & 133.85 & 859.48 \\
\hline \multicolumn{9}{|l|}{ 2. sampling } \\
\hline \multirow[t]{2}{*}{ Fertilization } & \multicolumn{2}{|c|}{ Weight of leaves $\mathbf{g ~ m}^{\mathbf{2}}$} & \multicolumn{2}{|c|}{ Weight of stems $\mathbf{g ~ m}^{2}$} & \multicolumn{2}{|c|}{ Weight of infl. $\mathbf{g ~ m}^{2}$} & \multicolumn{2}{|c|}{ Weight of plants $\mathbf{g ~ m}^{2}$} \\
\hline & 2010 & 2011 & 2010 & 2011 & 2010 & 2011 & 2010 & 2011 \\
\hline $\mathrm{H} 1$ & 402.20 & 334.28 & 1019.90 & 795.96 & 21.50 & 14.44 & 1443.60 & 1144.68 \\
\hline $\mathrm{H} 2$ & 468.20 & 370.16 & 1025.40 & 761.12 & 19.50 & 10.72 & 1513.20 & 1142.00 \\
\hline H3 & 672.90 & 518.08 & 1453.10 & 1041.56 & 10.80 & 23.32 & 2136.70 & 1582.96 \\
\hline $\mathrm{H} 4$ & 915.30 & 675.92 & 2139.40 & 1456.00 & 32.30 & 36.72 & 3087.00 & 2168.64 \\
\hline $\bar{x}$ & 614.62 & 474.61 & 1409.45 & 1013.66 & 21.03 & 21.30 & 2045.13 & 1509.57 \\
\hline \multicolumn{9}{|l|}{ 3. sampling } \\
\hline \multirow[t]{2}{*}{ Fertilization } & \multicolumn{2}{|c|}{ Weight of leaves $\mathbf{g ~ m}^{\mathbf{2}}$} & \multicolumn{2}{|c|}{ Weight of stems $\mathbf{g ~ m}^{2}$} & \multicolumn{2}{|c|}{ Weight of infl. $\mathrm{g} \mathrm{m}^{2}$} & \multicolumn{2}{|c|}{ Weight of plants $\mathbf{g ~ m}^{2}$} \\
\hline & 2010 & 2011 & 2010 & 2011 & 2010 & 2011 & 2010 & 2011 \\
\hline $\mathrm{H} 1$ & 382.60 & 262.60 & 1101.40 & 1789.52 & 158.60 & 282.92 & 1642.60 & 2335.04 \\
\hline $\mathrm{H} 2$ & 468.40 & 354.20 & 1253.20 & 2378.44 & 303.00 & 497.76 & 2024.60 & 3230.40 \\
\hline H3 & 844.20 & 650.57 & 1943.20 & 2631.19 & 414.40 & 666.51 & 3201.80 & 3948.27 \\
\hline $\mathrm{H} 4$ & 802.60 & 746.65 & 2057.80 & 2564.40 & 371.00 & 645.90 & 3231.40 & 3956.95 \\
\hline $\bar{x}$ & 624.45 & 503.51 & 1588.90 & 2340.89 & 311.75 & 523.27 & 2525.10 & 3367.67 \\
\hline
\end{tabular}

$13.8 \%(\mathrm{H} 4)$ in 2010. In 2011, higher values of the dry matter were reached than in the previous year. In fertilized variants, the average value was $18.84 \%$ and in the control variant, it reached $23.7 \%$.

The yields (dry matter) of amaranth in 2010 to 2011 indicate a high adaptability of the production potential in the monitored conditions.

The average biomass of dry matter harvested in the control treatment in $2010\left(1642.60 \mathrm{~g} \mathrm{~m}^{2}\right)$ was lower than in 2011 (233.045 $\left.\mathrm{g} \mathrm{m}^{2}\right)$.

The fertilization variants significantly affected the production of dry matter of amaranth cultivation in various years. The highest production was achieved in the $\mathrm{H} 4$ variant with the highest level of fertilization. The average value for both years in this variant was $3594.18 \mathrm{~g} \mathrm{~m}^{2}$ which represents an $87.8 \%$ increase in yield due to fertilization when compared to the control variant.

Our results in the unfertilized variant are comparable with the results of the EXBA Lower Malanta SPU Nitra for the period 1994-1996 when the Amaranthus hypochondriacus L. yield of 10.84 to $11.61 \mathrm{t} \mathrm{ha}^{-1}$ was reached (Pospišil 2010). The yields in the fertilized variants are also comparable with the yields from several sites in Slovakia (Húska 1997).
The whole growing season of 2010 was very wet; the precipitation reached $575 \mathrm{~mm}$ during this period (May to October). In terms of rainfall, the year 2011 was also favourable for production of dry amaranth matter. The precipitation values in May, June and July were higher than the long-term normal. In 2011, the total rainfall during the growing season (May-October) reached $360 \mathrm{~mm}$.

\section{Conclusion}

The course of meteorological elements in the observed years was relatively balanced. In the growing season on 2010 (May-October), the rainfall reached $575 \mathrm{~mm}$ and in 2011, it reached $360 \mathrm{~mm}$.

Although favourable agro-climatic conditions in 2011 enabled us to perform sowing 18 days earlier than in the previous year, because of the interaction of high precipitation values, we observed high values of aboveground biomass yield in both reference years (3231.40 and $3956.95 \mathrm{~g} \mathrm{~m}^{2}$, respectively).

A significant reaction of amaranth to different levels of nitrogen fertilization was observed. In the reference period, the biomass yield in the unfertilized variant reached $1988.82 \mathrm{~g} \mathrm{~m}^{2}$. In the fertilized variants, the yield ranged from 2627.50 to $3594.18 \mathrm{~g} \mathrm{~m}^{2}$. 
The high increase in biomass yields due to intensive fertilization was confirmed. The increase in yield due to nitrogen fertilization reached $1276.75 \mathrm{~g} \mathrm{~m}^{2}$ (64.20 \%).

\section{Acknowledgemets:}

The post was made with the financial support of the project VEGA: VMSP-0063-09: "The use of biomass for renewable energy production."

\section{References}

HABÁN, M. - ILLÉŠ, L. 2001. Produkcia semien genetických zdrojov láskavca (Amaranthus L.). In: Pestovanie a využitie tritikale, láskavca a pohanky, s. 50-53, 2001. ISBN 80-88943-07-8. HÚSKA, J. a i. 1997. Úroda nadzemnej biomasy vybraných druhov špeciálnych rastlín. In: Biologizácia rastlinnej výroby VII., Nitra : SPU, 1997, s. 42-44.

ILLÉŠ, L - ŽEMBERY, J. - CANDRÁKOVÁ, E. 2010. Hodnotenie ukazovatel'ov rastu a úrody semien láskavca. In: Zborník prednášok z VIII. zjazdu Slovenskej spoločnosti pre polnohospodárske, lesnícke, potravinárske a veterinárne vedy pri SAV v Bratislave, s. 57-63. ISBN978-80-552-0482-9.
JAMRIŠKA, P. 2001. Možnosti pestovania láskavca na Slovensku. In Pestovanie a využitie tritikale, láskavca a pohanky, 2001, s. 41-43. ISBN 80-88943-07-8.

POSPIŠIL, R. - HÚSKA, J. 2010. Úroda nadzemnej fytomasy láskavca Amaranthus hypochondriacus L. In Zborník prednášok z VIII. zjazdu Slovenskej spoločnosti pre polnohospodárske, lesnícke, potravinárske a veterinárne vedy pri SAV v Bratislave, s. 74-77. ISBN 978-80-552-0482-9.

ŽAJOVÁ, A. 2001. Štúdium botanicko-morfologických znakov rastlín láskavcov - Amaranthus L. In Pestovanie a využitie tritikale, láskavca a pohánky. Zborník vedeckých prác z konferencie s medzinárodnou účastou, Nitra, 2001, s. 44-46. ISBN 80-88943-07-8.

\section{Contact adress:}

Ing. Ladislav Illéš, PhD., Department of Plant Production, Faculty of Agrobiology and Food Resources, SUA in Nitra Tr. A. Hlinku 2, 94976 Nitra, e-mail: Ladislav.Illes@uniag.sk 